\title{
Essays
}

\section{Film as Witness: Screening Nazi Concentration Camps Before the Nuremberg Tribunal}

\author{
Lawrence Douglas ${ }^{\dagger}$
}

And then they showed that awful film, and it just spoiled everything.

Hermann Goering ${ }^{1}$

\section{INTRODUCTION: FILM AS WITNESS AND THE PROBLEM OF REPRESENTATION}

November 20, 1995 marks the fiftieth anniversary of the beginning of the most unusual judicial proceedings of the century, the Nuremberg war crimes trials. After a day devoted to entering the indictment and the pleas, Robert $\mathrm{H}$. Jackson, a sitting Justice of the U.S. Supreme Court and the chief counsel for the Allied prosecution, opened his address to the Tribunal with the words, "The wrongs which we seek to condemn and punish have been so calculated, so malignant, and so devastating, that civilization cannot tolerate their being ignored, because it cannot survive their being repeated."2 A week later, on the afternoon of November 29, 1945, Sydney Alderman, associate trial counsel, prepared the Tribunal for the presentation of the prosecution's most dramatic evidence of the Nazis' malignancy: "At this point it is planned by our staff to show a motion picture, and it will take some few minutes to make the physical

$\dagger$ Assistant Professor of Law, Jurisprudence \& Social Thought, Amherst College. I would like to thank Robert Bezucha, Robert Burt, Frank Couvares, Owen Fiss, Stephen Gardbaum, Leah Hewitt, Nancy Pick, Austin Sarat, Martha Umphrey, Sue Vice, and James Young for their helpful comments and suggestions. William Connelly, Research Librarian at the U.S. Holocaust Memorial Museum; William Murphy, former director of the Motion Picture and Sound Department at the National Archives; and Stephen Porder provided valuable research assistance. The writing of this Essay was generously supported by a Karl Loewenstein Fellowship in Jurisprudence.

1. See G.M. GILbERT, NUREMBERG Diary 49 (1947).

2. 2 TRIAL OF THE MAJOR WAR CRIMINALS BEFORE THE INTERNATIONAL MILITARY TRIBUNAL 98-99 (1947) [hereinafter IMT]. 
arrangements in the courtroom, so that if the Court should feel like recessing, those arrangements could be made."3

After the short recess, Thomas Dodd, executive counsel to the American prosecutorial team, described the purpose of the screening: "[T]his film which we offer represents in a brief and unforgettable form an explanation of what the words 'concentration camp' imply." Jackson himself had mentioned the film during his opening statement, as he offered the first description of the evidence that would introduce Nazi genocide to the law's ken:

We will show you these concentration camps in motion pictures, just as the Allied armies found them when they arrived .... Our proof will be disgusting and you will say I have robbed you of your sleep. ... I am one who received during this war most atrocity tales with suspicion and scepticism. But the proof here will be so overwhelming that I venture to predict not one word I have spoken will be denied. ${ }^{5}$

News of the camps, of course, had been broken months before the trial: British and American newspaper reports from Buchenwald and Belsen in late April and early May of 1945 had created a sensation. " "It is my duty," one British journalist had begun his dispatch, "to describe something beyond the imagination of mankind."" Generals Patton and Eisenhower, as was well publicized, had ordered every soldier not committed to the front line to visit the camps. ${ }^{8}$ Eisenhower himself had issued a terse statement, now etched into slabs of gray granite at the entrance to the U.S. Holocaust Memorial Museum in Washington, D.C.: "The things I saw beggar description . . . . I made the visit deliberately, in order to be in a position to give first-hand evidence of these things if ever, in the future, there develops a tendency to charge these allegations merely to "propaganda." "9

But rather than call Eisenhower to the stand, or any of the other thousands of soldiers who had been commanded to bear witness to Nazi atrocities, the prosecution turned instead to a novel witness-a documentary film. ${ }^{10}$ This

3. 2 id. at 431 .

4. 2 id.

5. 2 id. at 130 .

6. Historians, however, have demonstrated that news of the Nazi camps had found its way into the American press long before the liberation of the camps. Both the New York Times and the New York Herald Tribune had published accounts of the camps as early as 1942. See WalTER LAQUEUR, THE TERRIBLe SECRET: SUPPRESSION OF THE TRUTH ABOUT HITLER'S "FinAl SOLUTION" 74, 93 (1980).

7. Id. at 2.

8. Robert H. ABZUG, INSIDE the VicIOUS HEART: AMERICANS AND the Liberation of Nazi CONCENTRATION CAMPS 128 (1985).

9. Letter from General Dwight D. Eisenhower to General George C. Marshall (Apr. 15, 1945), reprinted in THE PAPERS OF DWIGHT DAVID EISENHOWER: THE WAR YEARS 2616 (Alfred D. Chandler ed., 1970).

10. Jackson in particular favored the use of captured documentary evidence, material he considered "harder" and less vulnerable to being discredited by defense attomeys practiced at the art of tendentious 
use of film in a juridical setting was unprecedented. ${ }^{11}$ Crime scene photography was well established in Anglo-American courts; and while the turn to filmic proof was perhaps a logical extension of available technology, it nevertheless marked a wholly new method of documenting criminality. Though motion pictures had been submitted as trial evidence as early as $1915,^{12}$ prior to Nuremberg, one can find no records of any court using graphic film of atrocities as proof of criminal wrongdoing. The use of film was necessitated, so the prosecution argued, by the nature of the crimes the Allies had assumed the burden of proving.

The Nazis themselves had recognized that the incredible nature of their atrocities would cast long shadows of doubt upon any allegedly eyewitness reports. Primo Levi describes how inmates at concentration camps heard the frequent taunt from their captors that should they survive, their stories would not be believed: "And even if some proof should remain and some of you survive, people will say that the events you describe are too monstrous to be believed: they will say that they are the exaggerations of Allied propaganda and will believe us, who will deny everything, and not you."13

The concern that allegations of atrocities would be dismissed as propaganda troubled the prosecution as well. Serious evidentiary questions, after all, had plagued the war crimes trials convened after World War I. While French, British, and American newspapers covering the Great War had routinely reported rumors of German acts of civilian slaughter, rape, and infanticide, most such stories were later exposed to be the prevarications of propagandists. ${ }^{14}$ The failure of the complaining parties (the French and British agitated to prosecute German war criminals over American objections) to support their allegations with credible evidence eroded the legitimacy of judicial proceedings anchored upon uncertain legal and jurisdictional

cross-examination. Prosecution counsel William Donovan's vehement argument that a greater reliance upon eyewitness testimony would have provided the trial with "an affirmative human aspect" led to his unceremonious removal from the prosecution team after the first week of the trial. See TELFORD TAYLOR, THE ANATOMY OF THE NuREMBERg TRIALS: A PERSONAL MEMOIR 146-49 (1992).

11. See ERIK BARNOUW, DoCUMENTARY: A HiSTORY OF THE NON-FICTION FILM 173-75 (2d rev. ed. 1993). See generally ILAN AVISAR, SCREENING THE HOLOCAUST: CINEMA'S IMAGES OF THE UNIMAGINABLE (1988) (discussing representation of Holocaust in different film genres).

12. Pierre R. Paradis, The Celluloid Witness, 37 U. CoLo. L. REv. 235, 235 (1965). In a famous early case, a "moving picture of plaintiff's performance in a vaudeville entertainment" had been introduced as evidence of the plaintiff's condition before a debilitating accident. Gibson v. Gunn, 202 N.Y.S. 19, 20 (App. Div، 1923) (per curiam), aff'd on reh'g, 202 N.Y.S. 927 (App. Div. 1924). The appellate court held that the film showing plaintiff's "eccentric dancing" and "comic songs" "tended to make a farce of the trial," as evidenced by the "excessive verdict returned by the jury." Id.

13. PRIMO LEVI, THE DROWNED AND THE SAVED 11-12 (Raymond Rosenthal trans., Vintage Int'l 1989) (1986) (paraphrasing SimON WIESENTHAL, THE MURDERERS AMONG Us (Joseph Wechsberg ed., 1967)).

14. See TAYLOR, supra note 10 , at 13 (discussing reports of conduct of German troops in Belgium); see also JAMES F. WILLIS, PROLOGUE TO NUREMBERG: THE POLITICS AND DIPLOMACY OF PUNISHING WAR CRIMINALS OF THE FIRST WORLD WAR 12-13 (1982). 
principles. ${ }^{15}$ Concerned about this precedent, Jackson, in a report sent to the President in June 1945, wrote, "We must establish incredible events by credible evidence."16

In response to this dilemma, the prosecution turned to documentary film. As the prosecution readied the Army's documentary for the Nuremberg Tribunal, James Donovan, an assistant trial counsel, expressed the idea succinctly. "[T]hese motion pictures," he announced, "speak for themselves in evidencing life and death in Nazi concentration camps . ..."17 The filmic witness could offer pictures where speech failed; it could produce visual knowledge of atrocities that resisted summary in the words of eyewitness testimonials. Such a view echoed an understanding that both saw documentary film as capable of offering a more complete and transparent window upon the "real,"18 and anticipated the crisis of representation that has come to characterize efforts to find an idiom capable of capturing the Holocaust's central horror.

The representational problems raised by Nazi genocide are familiar to Holocaust scholars. As Anton Kaes has observed, "The insistence on the impossibility of adequately comprehending and describing the Final Solution has by now become a topos of Holocaust research."19 Lawrence Langer, to take one important example, has argued that the conventions of nineteenthcentury literature rendered it "inadequate for the representation or evocation of the physical, moral, or psychological chaos" of the Holocaust. ${ }^{20}$ Langer's examination of literature's engagement with the Holocaust finds its analog in the works of scholars such as Lucy Dawidowicz ${ }^{21}$ and Zygmunt Bauman, ${ }^{22}$ who have studied the struggles of historical and sociological discourses to find

15. Article 228 of the Versailles Treaty required the German government to hand over its own citizens for war crimes trials to be conducted before tribunals of the victors. An initial Allied list of individuals to be surrendered named 854 persons, including many leading military and political figures. The storm of indignation unleashed in Germany led to a compromise between the Allies and the Germans: The Germans would try those accused of war crimes before the German Supreme Court in Leipzig. The Leipzig trials concluded in acquittals or short sentences, before being formally abandoned. See TaYLOR, supra note 10, at 16-18; see also Willis, supra note 14, at 126-47.

16. ROBERT H. JACKSON, THE NÜRNBERg CASE 10 (Cooper Square Publishers 1971) (1947). This concern also troubled Eisenhower. His famous statement, "The things I saw beggar description," poignantly expressed the dilemma of the observer who felt the ethical obligation to bear witness, yet whose language failed to provide the means to articulate what he had seen. As such, it powerfully anticipated George Steiner's aphorism, "The world of Auschwitz lies outside speech and it lies outside reason." GEORGE STEINER, $K$, in LANGUAGE AND SILENCE 118, 123 (1966).

17. 2 IMT, supra note 2 , at 433 .

18. In the words of the early film critic W. Stephen Bush writing about the First World War, "The only real and incorruptible neutral in this war is not the type but the film. . . . It is utterly without bias and records and reports but does not color and distort." W. Stephen Bush, War Films, 21 MOVING PICTURE WORLD 1617 (1914); see Anton Kaes, Holocaust and the End of History: Postmodern Historiography in Cinema, in PROBING THE LIMTSS OF REPRESENTATION 206, 208 (Saul Friedlander ed., 1992) (suggesting that what is not available to cognition through conventional idioms may be made available through film).

19. Kaes, supra note 18, at 207.

20. LAWRENCE L. LANGER, THE HOLOCAUST AND THE LITERARY IMAGINATION 15 (1975).

21. See LuCY S. DAWIDOWICZ, THE HOLOCAUST AND THE HISTORIANS (1981).

22. See Zygmunt Bauman, Modernity aND THE Holocaust 1-30 (1989). 
a form and grammar appropriate to the task of expressing the Holocaust experience.

The Nuremberg prosecution's turn to the filmic witness can thus be understood as an attempt to secure an adequate representation of "an order of reality which the human mind had never confronted before."23 This straightforward ambition, however, yielded less than straightforward results. The film Nazi Concentration Camps, as we shall see, was anything but an unambiguous document, and its use by the prosecution exemplifies how imperfectly evidence of Nazi genocide was presented and digested at Nuremberg. To appreciate this, it is important to consider the unique challenge that Nazi genocide presented to the law. Distinct from history, literature, and those disciplines burdened with finding an appropriate manner of representing the Holocaust, the law had to locate an adequate idiom of both representation and judgment. The Nuremberg prosecution could not simply gesture toward evidence of unspeakable atrocities by darkening a courtroom and showing a film; it had to present proof that would support the pronouncement of a legal judgment.

Yet as an examination of the documentary Nazi Concentration Camps and the legal case in which it was enlisted as proof reveals, the task of shaping an adequate idiom of both representation and judgment often pulled the prosecution in opposite directions. While the film offered visual proof of astonishing atrocities, the very unprecedented nature of the crimes to which it bore witness complicated attempts at assigning blame and seemed to undermine the jurisprudential theories upon which the Allied prosecution was based. For the horror of the Nazis' crimes lay not only in their concrete detail, but also in their symbolic content. By challenging the capacity of the Nuremberg Tribunal to comprehend the practice of genocide in terms of conventional violations of ordered legality, Nazi practices threatened to expose law's limits.

A study of the prosecution's response to this challenge-its attempt to reconcile the task of representation with the burden of judgment-will highlight the power of legal discourse to frame our understanding of visual images. It will also, however, reveal how the extraordinary effort to accommodate Nazi genocide to prior conceptions of legality and criminality resulted in a failure to grasp the nature and meaning of the effort to exterminate Europe's Jewish population. Ultimately, this failure can be seen as the predictable, if not inevitable, consequence of an attempt to comprehend an unprecedented evil through an idiom whose authority is anchored in the concept of precedent-and in the belief that all crimes can and must be judged according to familiar principles filtered through past practice.

23. LANGER, supra note 20 , at 3. 
Yet the very failure of the Nuremberg prosecution to represent adequately the nature and meaning of Nazi genocide also constituted a juridical success. By translating evidence of unprecedented atrocity into crimes of war, the Nuremberg prosecution was able to create a coherent and judicially manageable narrative about crimes so radically alien that they seemed to defy rational and juridical explanation.

\section{SCREENING NAZI CONCENTRATION CAMPS}

If filmic testimony could supply credible, indeed irrefutable, evidence of unprecedented crimes, what exactly did the Tribunal see when the prosecution screened Nazi Concentration Camps? This seemingly straightforward question is critical if we are to understand how the prosecution attempted to translate images of atrocity into a coherent legal idiom. While the official transcript of the proceedings before the International Military Tribunal is helpful in reestablishing the circumstances surrounding the showing of the documentary, it also frustrates the effort. James Donovan (the assistant prosecutor who claimed the film would speak for itself) informed the court that the footage had been "compiled from motion pictures taken by Allied military photographers as the Allied armies in the West liberated the areas in which these camps were located." 24 Some 80,000 feet of tape had been edited into about 6,000 feet of film with a running time of a little over an hour. ${ }^{25}$ The accompanying narration, Donovan noted, had been "taken directly from the reports of the military photographers who filmed the camps."26

According to the official transcript, "photographs were then projected on the screen showing the following affidavits while at the same time the voices of the respective affiants were reproduced reading them."27 The first affidavit belonged to Lieutenant Colonel George C. Stevens, who was already a wellknown Hollywood director before he joined the Army Signal Corps, and who in the 1950s would reach greater fame through films such as Shane, A Place in the Sun, and The Diary of Anne Frank. Responsible for the "photographing of the Nazi concentration camps and prison camps as liberated by Allied Forces," Stevens certified that "these motion pictures constitute a true representation of the individuals and scenes photographed." 28 The second affidavit, that of E.R. Kellog, a "director of film effects" who had examined the film, certified "that the images of these excerpts from the original negative have not been retouched, distorted or otherwise altered in any respect."29

\footnotetext{
24. 2 IMT, supra note 2 , at $432-33$.

25. 2 id. at 434 .

26. 2 id. at 433 .

27. 2 id.

28. $2 i d$.

29. 2 id. at 434 .
} 
Yet after the dramatic buildup preparing the court for the documentary, the trial transcript suddenly turns laconic:

[The film was then shown.]

COL. STOREY: That concludes the presentation.

[The Tribunal adjourned until 30 November 1945 at 1000 hours.] $]^{30}$

The morning session on Friday, November 30, began without any mention of the film, as the prosecution turned from an earlier discussion of the Austrian Anschluss to the seizure of the Sudetenland. Yet the failure to refer to the film does not indicate that the documentary left the court unmoved. As one news account filed from the trial makes clear, the spectators were so disturbed that " $[t]$ he presiding judges retired without a word and without announcing as usual the time set for the next session."31 Even contemporaneous journalistic accounts, however, as well as memoirs written years later, fail to make clear what the Tribunal saw. Under the title "War-Crimes Court Sees Horror Films," the New York Times ran an article on November 30 that observed:

The coolest and most collected spectators were the prisoners, whose rapt expressions were illuminated by the dimmed lights along the front of the dock. All but Schacht followed every scene of the film, leaning forward to get a better view.... The only other prisoner affected ... was von Ribbentrop, who watched the first third of the film and then turned away and closed his eyes for most of the remainder, taking only an occasional glance at the screen as if urged to it by some horrible fascination. ${ }^{32}$

G.M. Gilbert, who served as the prison psychologist at Nuremberg, offers, however, a dramatically different account of the screening in the diary that he kept at the time:

Funk covers his eyes ... Sauckel mops brow ... Frank swallows hard, blinks eyes, trying to stifle tears ... Frank mutters "Horrible!" . . Rosenberg fidgets, peeks at screen, bows head, looks to see how others are reacting ... Seyss-Inquart stoic throughout ... Speer looks very sad, swallows hard ... Defense attorneys are now muttering, "for God's sake-terrible." . . . Fritzsche, pale, biting lips, really seems in agony ... Doenitz has head buried in his hands ... Keitel now hanging head. ${ }^{33}$

30. $2 \mathrm{id}$. Though this short sequence was the only description of the film's presentation in the actual trial transcript, a transcript of the film's narration was included in the volume titled "Documents and Other Material in Evidence," which was appended to the trial transcript. See 30 id. at 462-72.

31. Atrocity Films in Court Upset Nazis' Aplomb, N.Y. HERALD TRIB., Nov. 30, 1945, at 11; see also Nazis on Trial See Horror Camp Film, WASH. POST, Nov. 30, 1945, at 2.

32. Raymond Daniell, War-Crimes Court Sees Horror Film, N.Y. TIMES, Nov. 30, 1945, at 6.

33. GILBERT, supra note 1 , at 45-46. 
In his 1978 memoir, Airey Neave, who as a twenty-nine-year-old Oxford lawyer assisted the British prosecutorial staff at Nuremberg, described the impact of the screening upon the courtroom in somewhat different terms:

Several in the darkened courtroom were faint or sobbed quietly at the scenes described by a burly British lieutenant-colonel as he stood among the dead and dying of Belsen....

... During the showing of the film, the dock, as a measure of security, was picked out by small spotlights. Few of the defendants could bear to watch the whole film. ...

I cannot forget the sudden vision of those twisted guilty faces . . . with tears on their cheeks. I sometimes dream of it. ${ }^{34}$

More recently, Telford Taylor, who served as associate trial counsel, remembered the screening in his 1992 memoir The Anatomy of the Nuremberg Trials:

Dr. von der Lippe recorded that the film would rob its viewers of sleep and that he had heard one of the defense counsel say it had become intolerable to sit in the same room with men like Kaltenbrunner and Frank. Schacht turned his back on the screen to show that he had had no connection with such bestiality; Goering tried to brazen it out; the weaker ones like Ribbentrop, Frank, and Funk appeared shattered. ${ }^{35}$

Despite their differences, all four accounts share an interesting rhetorical feature. We are supplied with the barest description of the actual images projected in the film. Instead, we are asked to see the film voyeuristically through the eyes of not just any viewers, but of those allegedly responsible for the very atrocities captured on film. Such a technique thus supports the idea that the atrocities projected on the screen defeat and silence efforts of verbal summary. Indeed, the technique itself partakes of a cinematic logic, as the spectator, caught between voyeurism and revulsion, finally breaks his gaze away from the images of atrocity and turns toward the perpetrators. Their agitation seems baffling: We are left wondering whether the defendants had never before seen or imagined the atrocities they had orchestrated, or whether the realism of the filmic representations, their construction from an outsider's perspective, produced an awareness among the defendants greater than that gained through their engagement as Nazi functionaries. ${ }^{36}$ The melodrama of the scene is underscored by Neave's description of the defendants' dock discreetly illuminated by small spotlights. And while Taylor recalls that the

34. Airey NeAVE, ON TRIal at NuREMBERg 247 (1978).

35. TAYLOR, supra note 10 , at 187.

36. Martha Umphrey suggested this insight in conversation. 
defense counsel von der Lippe feared the film would deprive its viewers of sleep, it is not the images from the documentary that recur in Neave's dreams, but the expressions on the defendants' faces.

By focusing on the Nazi defendants, both the transcript and the memoirs unfortunately leave us in the dark about what the Tribunal saw in Nazi Concentration Camps. This, of course, is not accidental, as the authors of the memoirs do not resolve the defendants' legal culpability as much as presuppose it. They ask us to see the defendants through the reflection of atrocities in their eyes. By neglecting to make clear what the court actually saw in Nazi Concentration Camps, the journalists and memoirists only reinforce an understanding that the images "speak for themselves" as to the defendants' guilt.

Yet guilty of what? If the question seems misplaced or even grotesque given our knowledge of Nazi atrocities, it is worth recalling that the Nuremberg trial was dedicated to proving, not assuming, that the accused had engaged in criminal acts as defined by relevant law. As Taylor himself has observed, "The public showing of the film certainly hardened sentiment against the defendants generally, but it contributed little to the determination of their individual guilt." ${ }^{37}$ Indeed, the very unnamed repulsiveness of the film's images can be seen to have complicated rather than simplified the legal issues before the Tribunal. If evidence of Nazi atrocities exhausted linguistic reserves, then how can such images be assimilated into a meaningful juridical decree? How can images of unprecedented horrors be used to support a legal judgment whose legitimacy is anchored in the concept of precedent? To answer these questions, it is necessary to turn attention away from the problem of representation to the problem of judgment, and to examine the legal idiom used by the prosecution to translate images of atrocity into a discourse of illegality.

\section{ARENDT ON NAZI ATROCITIES: EXPLODING LAW'S IDIOM}

Even in the waning moments of the war, it was far from clear that the Allies would use the arm of the law to punish the Nazi leadership. The British, for example, resisted the idea of trying the various heads of state, favoring instead the summary execution of a dozen or so leading members of the Nazi apparatus-a symbolic yet tangible punishment of a criminal state's most visible functionaries. ${ }^{38}$ The proposal enjoyed the virtue of simplicity. It would

37. TAYLOR, supra note 10 , at 187.

38. The British proposal also enjoyed Soviet support; indeed, Stalin, in a "half-serious recommendation," suggested that 50,000 German general staff officers be shot. Such proposals arose from American circles as well: Joseph Pulitzer, the newspaper tycoon, urged in May 1945 the shooting of 1,500,000 Nazis. Morgenthau also prominently recommended that major war criminals be summarily executed. See István Deák, Misjudgment at Nuremberg, N.Y. REV. BooKs, Oct. 7, 1993, at 48 \& n.8 (reviewing TAYLOR, supra note 10). For histories of the competing proposals, see TAYLOR, supra note 10, 
spare the Allies the tedious process of quickly organizing a vast amount of material into a legal case, and would deprive the guilty of an opportunity to vex prosecutors through dilatory tactics and legalistic casuistry. As the jurisdictional bases of any formal action against former heads of state would be vulnerable to legitimate dispute, summary execution also had the added attraction of candor: The victors would not attempt to rationalize or disguise a punishment exacted by one sovereign upon another by appeal to the neutral instrument of the law.

The British position implicitly found support among various thinkers who expressed deeper doubts about the efficacy of relying upon a legal response to atrocities perpetrated on such a vast scale. Commenting on the Nuremberg proceedings years before she would serve as the New Yorker's correspondent on the Eichmann trial, Hannah Arendt observed:

The Nazi crimes, it seems to me, explode the limits of the law; and that is precisely what constitutes their monstrousness. For these crimes, no punishment is severe enough. It may well be essential to hang Göring, but it is totally inadequate. That is, this guilt, in contrast to all criminal guilt, oversteps and shatters any and all legal systems. That is the reason why the Nazis in Nuremberg are so smug. . . . We are simply not equipped to deal, on a human, political level, with a guilt that is beyond crime ....

While Arendt's statement remains question-begging-she never offers an understanding of "normal" criminal guilt and as a consequence fails to specify the manner in which the Nazis' crimes "explode the limits of the law"-she also gives voice to the important insight that the Nazis' crimes threaten to unsettle the most fundamental conceptions of personal responsibility, moral choice, and legal normativity upon which Western jurisprudential understandings are predicated. As such, her statement resonates with, and helps elaborate, the reasoning behind the British proposal.

Arendt does not, for example, argue that the enormity of the Nazis' crimes supplies an argument against punishment. Quite to the contrary, the need for the most extreme punishment can never be seriously questioned. Indeed, the insufficiency of even the most violent sanctions to fit the crimes only underscores the inadequacy of a legal response. If the controlling trope of Anglo-American law is the scales of justice, ${ }^{40}$ this device is meant not only to measure the formal proof in a given case, but also to strike a balance between the wrong committed and the sanction imposed. The common

at 25-40, and Steven Fogelson, Note, The Nuremberg Legacy: An Unfulfilled Promise, 63 S. CAL. L. REV. $833,836-45$ (1990).

39. HANNAH ARENDT, KARL JASPERS CORRESPONDENCE 1926-1969, at 54 (Lotte Kohler \& Hans Saner eds., Robert Kimber \& Rita Kimber trans., 1992) (footnote omitted).

40. See Dennis E. Curtis \& Judith Resnik, Images of Justice, 96 YALE L.J. 1727, 1731 (1987). 
challenge to legal justice comes from the failure to strike this balance in a fair manner: The requirements of a just resolution are not satisfied when the scales are tipped in the direction of violence imposed in the law's name. The Nazis' crimes, by contrast, offer a more extraordinary challenge to this concept of legal justice, as no amount of juridically authorized violence will ever even the scales against the impossible burden of genocide. Thus the problem, as Arendt conceives it, is not that the law will fail to do justice to the defendants; rather, it is that the crimes of the defendants have so distorted the meaning of legal justice that the law will not do justice to itself. The Nazis' crimes, as captured in material such as Nazi Concentration Camps, make futile the effort to unite a jurisprudential vision with the imposition of a violent sanction.

In this regard, Arendt's critique remains metadoctrinal. The Nazis' crimes, she suggests, make embarrassingly visible the shortcomings of any jurisprudential theory that seeks to locate and anchor law's normativity in the commands of a sovereign. ${ }^{41}$ Moreover, Nazi atrocities undermine and erode confidence in many of the foundational concepts upon which the rule of law is predicated. The belief that the state can be relied upon as the locus of legal authority, that wrongdoing proliferates only in the absence of societal rules, and that criminality is no more than an anomalous and discrete state of affairs, are all notions that can barely survive contact with the images of the concentration camps. Arendt's argument thus implicitly supports the British proposal in questioning the law's capacity to provide an adequate response to Nazi atrocities.

\section{JACKSON AND THE PROSECUTION'S IDIOM OF JUDGMENT}

The Americans, however, insisted upon a juridical response to the Nazis' crimes. Murray Bernays, who largely shaped the case's jurisdictional and substantive framework, understood, in important respects, the insight that the Nazis' crimes threatened to expose law's limits. ${ }^{42}$ For Bernays, however, it was the very seriousness of the challenge that intensified the need for a legal response. Bernays pioneered the use of the concept of criminal conspiracy as the organizing principle of the prosecution. Such a charge, he argued, could effectively link a diverse group of defendants to a broad array of crimes. ${ }^{43}$

Jackson formalized the broad principles of Bernays's approach into the four-count indictment: first, the conspiracy charge; second, "Crimes Against

41. For a classic statement of the positivist position, see JOHN AUSTIN, LECTURES ON JURISPRUDENCE OR THE PHILOSOPHY OF POSITIVE LAW (London, John Murray 1885); H.L.A. HART, THE CONCEPT OF LAW 181-207 (1961).

42. The gradual rallying of support-in both American circles and abroad-for Bernays's juridical solution is well documented. See TAYLOR, supra note 10, at 35-42; Fogelson, supra note 38, at 861-67; see also WHITNEY R. HARRIS, TYRANNY ON TRIAL (1954).

43. TAYLOR, supra note 10 , at 35-36. 
the Peace," that is, the crime of waging aggressive war; third, "War Crimes"; and fourth, "Crimes Against Humanity."44 Jackson understood that the Allies invited the charge of conducting a victor's trial by bringing criminal proceedings against former heads of state. ${ }^{45}$ Sensitive to this critique, he insisted that it was incumbent upon the proceeding to rebut, in its form and substance, the charge that it was no more than a partisan exercise in the relativity of justice. Only in so doing, he argued, could the Tribunal claim that power and the "hand of vengeance" had been disciplined and checked by reason. ${ }^{46}$

For the purpose of understanding the prosecution's provocative use of $\mathrm{Nazi}$ Concentration Camps, however, it is necessary to consider how Jackson sought to rebut the objection that the Nuremberg proceeding represented no more than the imposition of the standards of one sovereign upon the leaders of another. This critique, as articulated by scholars such as Hans Kelsen, ${ }^{47}$ specifically questioned the legal adequacy of Article I of the indictment, "Crimes Against the Peace"- the charge that emerged as the gravamen of the prosecution's case.

Whether waging a war of aggression constituted a punishable crime in positive law was a question that aroused intense debate within the prosecution itself. The French, in particular, resisted the inclusion of "Crimes Against the Peace," and argued instead that "War Crimes" and "Crimes Against Humanity" should be the focus of the Allies' case..$^{48}$ Although sound doctrinal grounds seemed to support the French position-international law and custom seemed less ambiguous in their condemnation of extermination than in their rejection of aggressive militarism - the Americans, and in particular Jackson, vehemently argued that belligerent militarism remained the greatest threat to world peace and could be understood as the proximate cause of the Nazis' other crimes. ${ }^{49}$

One consequence of this approach can be seen in the Tribunal's restrictive reading of the fourth count of the indictment, "Crimes Against Humanity." While such a count would seem to provide the Court with sweeping power to

44. The definitions of "Aggressive War," "War Crimes," and "Crimes Against Humanity" are provisionally offered in the "Indictment." See 1 IMT, supra note 2, at 27-68. The Americans were responsible for presenting the case for the first count, the British presented the second, and the French and Russians jointly presented the third and fourth counts.

45. Some legal scholars have attempted to answer the victor's trial charge by pointing out that all criminal trials are, in a sense, victor's trials-as the presence of any defendant in a courtroom already speaks of the victory of the state's powers of detection and discipline over the accused. More specifically, Herbert Wechsler, who served as a legal adviser to Judge Biddle, pointed out that crimes such as treason rely upon a logic not dissimilar from that employed by the Tribunal. See HERBERT WECHSLER, The Issues of the Nuremberg Trial, in PRINCIPLes, Politics, AND FundaMental LAW 138, 144-45 (1961). A rejoinder and fresh elaboration of the victor's trial critique is offered by Desk, supra note 38, at 51-52.

46. 3 IMT, supra note 2 , at 99.

47. Hans Kelsen, Will the Judgment in the Nuremberg Trial Constitute a Precedent in International Law?, 1 INT'L L.Q. 153, 154-59 (1947).

48. See TAYLOR, supra note 10 , at $64-67$.

49. See id. at 76-77. 
act in defense of "universal" human rights, the Tribunal interpreted the London Charter (the international agreement that called into being the Nuremberg proceedings and defined the Tribunal's jurisdiction) as restricting its authority and allowing punishment of such offenses only if committed in furtherance of "planning, preparation, initiation or waging of a war of aggression." As Jackson expressed the idea: "Th[e] attack on the peace of the world is the crime against international society which brings into international cognizance crimes in its aid and preparation which otherwise might be only internal concerns." ${ }^{\text {"II }}$ Thus, under this interpretation, whatever crimes against humanity the Nazis committed against German citizens before the Wehrmacht crossed the Polish border did not fall under the jurisdiction of the Nuremberg court. At the heart of this position were the Allies' (principally the Russians', though the Americans' as well) worries that too robust a concept of crimes against humanity would supply a potentially unattractive precedent for challenging a sovereign's control over its own domestic population. As a jurisprudential matter, then, the prosecuting authorities' decision to focus on aggressive warfare led to a restrictive reading of the charge that covered the Nazis' worst atrocities. ${ }^{52}$ Against the rights of humanity, Nuremberg deferred to the superior claims of sovereignty.

The result of refusing to consider crimes against humanity as a punishable offense independent of any connection to the crime of waging aggressive war was that the soundness of this count of the indictment rested upon the legitimacy of the "Crimes Against the Peace" count. ${ }^{53}$ On one level, this

50. 1 IMT, supra note 2 , at 11 . The reasons for the Tribunal's restrictive reading of the fourth count are largely a result of the Charter's restrictive definition of the conspiracy charge which, in its final form, only applied to the aggressive war charge. Thus Article 6 of the Charter, as finally agreed on, did not include a charge of conspiracy to commit war crimes or other atrocities. As Taylor has argued, this was a "disastrous blow" to Bernays's original proposal, as the very logic of the conspiracy charge was to criminalize prewar atrocities. Why Jackson acceded to this modification of the Charter is not completely clear. Taylor argues that Jackson "either overlooked the effect of the change or did not care; for him the conspiracy charge had always been important primarily in aid of proving individual guilt for waging aggressive war, and its role as a device for criminalizing prewar atrocities may not have been in the forefront of his mind." TAYLOR, supra note 10, at 76. Though the prosecution during the trial tried to include prewar atrocities as actionable under the conspiracy charge, the Tribunal interpreted Article 6 to apply exclusively to the charge of waging aggressive war.

51. 2 IMT, supra note 2 , at 103.

52. Of course, the Allies also had sound doctrinal reasons for restricting the crimes against humanity charge to acts committed in furtherance of the war of aggression, as international law and custom did not offer firm support for the authority of one sovereignty to pass judgment on the leaders of another sovereignty for their treatment of their own domestic population. See ROBERT K. WOETZEL, THE NUREMBERG TRIALS IN INTERNATIONAL LAW 184 (1960). As Woetzel put this point:

Thus, even if the acts of nationals of one state against citizens of the same state amounted to the most flagrant violations of fundamental principles of civilised behaviour as recognised by most nations, it is not certain that this fact alone would constitute sufficient legal basis for Id. holding individuals criminally responsible for them.

53. Unfortunately, however, this count has not escaped vociferous challenge. This attack, a variation of the positivist critique, insists on the basic similarity between the actions of the vanquished and the victor. Nations throughout history, the argument goes, have used warfare as a means of advancing diplomatic and strategic ends; to treat such behavior as criminal is simply to increase the penalties for the defeated's 
appeared a questionable move, as notwithstanding Jackson's attempts to appeal to a body of international law, treaty, and custom ${ }^{54}$ many commentators have remained unconvinced by the attempt to criminalize aggressive war. ${ }^{55}$ On another level, however, Jackson's jurisprudential argument can be understood as mindful of Arendt's concern that the Nazis' crimes glaringly revealed law's limits. By treating crimes against humanity as ancillary to the principal crime of military aggression, Jackson's approach shifted attention away from those atrocities that presented, in Arendt's mind, the greatest challenge to the concept of ordered legality. While criminalizing military belligerence can be dismissed as an exercise in futility, the acts that Jackson sought to punish can be seen as less disruptive of jurisprudential assumptions than genocide. Genocide, as Arendt suggests, undermines confidence in all jurisprudential understandings, be they inspired by natural or positive law traditions. The criminalization of aggressive warfare, unusual as this may be, represents no more than the extension of legal principles that control domestic conduct into relations between nations. As Sir Hartley Shawcross declared in his opening statement for the British prosecution: "If murder, rapine, and robbery are indictable under the ordinary municipal laws of our countries, shall those who differ from the common criminal only by the extent and systematic nature of their offenses escape accusation?"56

This attempt to cast extraordinary legal arguments in terms of conventional legal understandings is best captured in the analogy Jackson drew between international and common law:

[International law] grows, as did the common law, through decisions reached from time to time in adapting settled principles to new situations. The fact is that when the law evolves by the case method, as did the common law and as international law must do if it is to

ultimate crime: losing. A victor's trial represents no more than the attempt to exact punishment for the defeated's failure to win. Indeed, this argument found widespread sympathy within the allied prosecution, particularly among the French. As one member of the French prosecution declared, "We do not consider as a criminal violation the launching of a war of aggression." TAYLOR, supra note 10, at 65-66. Though the French ultimately agreed to the American plan, they continued to believe that the "war crimes" and "crimes against humanity" charges should have remained the gravamen of the complaint. For a positivist critique of the aggressive war charge, see Kelsen, supra note 47, at 156-59, and for a more general polemic against the trial, see Werner MASER, NüRNBERG: TRIBUNAL DER SIEGER 517-608 (1977).

54. Though the Americans were formally charged with presenting the first count of the indictment (the conspiracy count), this charge essentially presented Jackson with the opportunity to examine extensively the second count (waging aggressive war). See Fogelson, supra note 38, at 850 .

55. Jackson was correct that the Briand-Kellogg Pact, adopted by the League of Nations in 1928 with Germany as a signatory, banned the waging of aggressive war, and thus seemed to tender the positive law basis for criminalizing the waging of aggressive war. But the Pact also famously failed to define the meaning of "aggressive war," neglected to specify who may supply the missing definition, and left unanswered what sanctions could be levied against a violator and by whom. See Kelsen, supra note 47, at 156-59; see also Otto Kranzbuhler, Nuremberg Eighteen Years Afterwards, 14 DEPAUL L. REV. 333, $343-45$ (1965) (noting difficulty in defining and assigning blame for crime of aggressive war).

56. $3 \mathrm{IMT}$, supra note 2 , at 92 . 
advance at all, it advances at the expense of those who wrongly guessed the law and learned too late their error. ${ }^{57}$

By appealing to the example and positive presence of the common law, Jackson brilliantly attempted to preserve the available idiom of the law while enlisting it to give order to a realm that had never been adequately and intelligibly subjected to legal administration and judgment. In so doing, Jackson extended the common law method to a metadoctrinal level: The specific case no longer supplies the precedent to the subsequent holding; now it is the very method of lawmaking through judicial accretion that supplies the precedent for, and thus legitimizes, the Tribunal's power to reach a legal decision. Thus, by asking his audience to imagine international law as a subspecies of domestic common law (instead of vice versa), Jackson was able to stretch the law's power of legitimate sanction without altering its basic and familiar idiom.

Nuremberg, for Jackson, was ultimately an exercise in law's selfreconstitution. The Tribunal, he argued, had not only to demonstrate that it was a neutral forum of judgment; it had to demonstrate law's power to reintroduce its ordering effects-both administratively and normatively understood-into a space of spectacular excess and egregious lawlessness. ${ }^{58}$ By conceptualizing the pathologies of modern warfare as legally cognizable and punishable crimes, and by legitimatizing the Tribunal's power to exercise jurisdiction over these wrongs through appeal to the common law, Jackson showed how law's conventional idiom could be modified to discipline the most extreme excesses. In contrast to Arendt's focus on genocide, Jackson shifted the Tribunal's attention to the widespread, but judicially manageable, crimes of belligerent militarism.

\section{THE TENSION BETWEEN REPRESENTATION AND JUDGMENT: THE PLIGHT OF THE CAMERA}

If Jackson attempted to justify criminalizing aggressive militarism by speaking the familiar (at least in Anglo-American circles) language of the common law, how does this explain the prosecution's use of Nazi Concentration Camps? We have already observed that the statements of the prosecution that the images "speak for themselves," while perhaps useful in justifying the introduction of the film as a witness, also threatened to unsettle

57. 2 id. at 147.

58. Arendt, by contrast, seems to understand the application of positive laws in much the same way as the modern physicist understands the application of physical laws. They are capable of controlling the behavior of conventional objects, yet become stretched beyond meaning when they are applied to extraordinarily large and refractory phenomena. Jackson, however, believed the law's power to control conventional situations demonstrated its power to control extremes. 
any effort to reconcile the outrages captured on film with Jackson's theory of the prosecution's case. Indeed, for his theory to be consistent, Jackson had to maintain exactly what the prosecution tacitly called into question by introducing the filmic testimony. He had to claim that the images did not exhaust law's capacity to unite proof of criminal wrongdoing with a just and measured punishment. With this tension in mind, how can one harmonize the evidence presented to one's eyes with Jackson's unusual, yet in many respects, deeply conventional, idiom of criminality?

To view Nazi Concentration Camps today unfortunately provides an imperfect idea of what the Tribunal saw fifty years ago. The horror captured in Nazi Concentration Camps is by now so familiar that it is difficult to imagine an original screening-that is, a screening that shocks not simply because of the barbarity of the images, but also because of their novelty. By familiar, however, I do not mean to suggest that the actual images shown in the film trigger the same visual recognition of, for example, the Zapruder film of the Kennedy assassination-though the scenes of British soldiers bulldozing heaps of rotting corpses into mass graves at Bergen-Belsen certainly remain among the most harrowing and recognizable documentary footage associated with the end of the war. Rather, I mean to suggest that the filmic landscape that we inhabit is very much the visual legacy of films such as this, a cultural universe defined by the production and circulation of graphic images of extreme violence.

Film had, of course, discovered the allure of warfare on the battlefields of the First World War, when battle sequences were shown in weekly British and American news reels. ${ }^{59}$ Yet these films rarely showed graphic shots of the war dead. ${ }^{60}$ Indeed, as George Roeder has observed, because of "the technical limitations of early twentieth century photography, the most striking images to come out of World War I were written ones."61 Earlier still, Mathew Brady's photography of the Civil War had demonstrated the special relationship between photography and death: how the stillness of the image demonstrates formal affinities with death's repose (in an age of slow shutter speeds, the dead struck the most cooperative poses). ${ }^{62}$ Perhaps not coincidentally, George C.

59. MiCHAEL T. ISENBERG, WAR ON FILM: THE AMERICAN CINEMA AND WORLD WAR I, 1914-1941 passim (1981).

60. See id. at 74.

61. GEORGE H. ROEDER, JR., THE CENSORED WAR: AMERICAN Visual EXPERIENCE DURING WORLD WAR TWO 17 (1993).

62. A pictorial album of Brady's photography is provided in JAMES D. HORAN, MATHEW BRADY: HISTORIAN WITH A CAMERA (1955). Barthes, for example, drew attention to "that rather terrible thing which is there in every photograph: the return of the dead." Michael Renov, Toward a Poetics of Documentary, in THEORIZING DOCUMENTARY 12, 25 (Michael Renov ed., 1993) (citing ROLAND BARTHES, CAMERA LUCIDA: REFLECTIONS ON PHOTOGRAPHY 9 (Richard Howard trans., 1981)). But the relationship between photography and death that Barthes named is very different from what I have in mind. If Barthes intended to identify the eerie temporality of photography, the image's resistance to the decay of that which it represents, war photography discovers a disturbing harmony between the dead subject and the still image. (For a remarkable study of the aesthetics of the photographed murder victim, see LUC SANTE, EVIDENCE 
Stevens was a great admirer of Mathew Brady's work - he owned, at the end of his life, a large collection of the Unionist's photographs. ${ }^{63}$ But by ushering film into a new, and at the time, unknown terrain of violence and horror, Stevens's Nazi Concentration Camps did less to extend Brady's legacy than to exhaust it. ${ }^{64}$

In this regard, the magnitude of the atrocities committed as well as the clarity and immediacy of the film's representations seemed unprecedented..$^{65}$ Commenting on the photographic stills from the camps, Susan Sontag writes:

Nothing I have seen-in photographs or in real life-ever cut me as sharply, deeply, instantaneously. Indeed, it seems plausible to me to divide my life into two parts, before I saw those photographs (I was twelve) and after.... When I looked at those photographs, something broke. Some limit had been reached, and not only that of horror ....66

By providing a visual register of atrocity, Nazi Concentration Camps crossed a threshold of representation from which there was no turning back. But if our presence in a culture saturated with images of extreme violence makes it difficult to view the documentary with the innocence of the contemporaneous spectator, it also makes it easier, less sacrilegious, to consider critically what we have seen. Because we have seen these images before, we are free, as the first observers were not, to examine their structure, meaning, and uses as representations.

Nazi Concentration Camps begins by testifying to its own authenticity. The trial transcript, as we have seen, notes that pictures of various affidavits

(1992)). Film, by contrast, provides the documentation not of death's stillness, but of the instant of its violent intrusion.

63. See MAX HASTINGS, VICTORY IN EUROPE 10 (1985).

64. One could argue that it is only fitting that George C. Stevens should be credited with the film, as the very innocence of the cinematic art is registered upon the prewar work of this popular Hollywood director. Esteemed for his romantic comedies, Stevens's work typified a cinematic vision that united an attimes edgy critical eye with a fundamentally benign outlook on the nation. If he searched for fresh and entertaining twists on the romantic struggle between individual and society, the range of reality known to Stevens's films largely exhausted the world as known to American film: Images of frustrated courtship and working class hardship were digested in a larger mosaic of honest individuals searching for meaning among local attachments. Although Nazi Concentration Camps displays many of the virtues that distinguished Stevens's filmmaking - classically framed panoramas that dissolve into fastidiously composed close-ups, arresting stills, unsettling juxtapositions-these technical gifts find themselves now enlisted to create a work that explodes the very filmic universe his Hollywood career had served to build. See generally DONALD RICHIE, GEORGE STEVENS: AN AMERICAN ROMANTIC (photo. reprint 1985) (1970).

65. Yet as George Roeder has demonstrated, the censoring and suppression within the United States of horrific battlefield images from the American theater in World War II intensified and complicated the response to film of German atrocities. Pictures of horrors from culturally remote areas-such as those committed by the Japanese upon the Chinese-were, by contrast, more widely circulated. ROEDER, supra note 61 , at $125-27$.

66. SUSAN SONTAG, ON PHOTOGRAPHY 20 (1977). Yet, once this limit has been reached, Sontag notes how quickly the individual becomes immune to any effect the photographs might originally have had: "Once one has seen such images, one has started down the road of seeing more-and more. . . . The shock of photographed atrocities wears off with repeated viewings ...." Id. 
supporting the film's accuracy were projected before the Nuremberg court. What the transcript fails to make clear, however, is that these affidavits are part of the film itself, and the voice that reads them aloud is part of the sound track. This gesture of self-authentication thus supports the novel understanding of the documentary as a privileged witness independently competent to swear to the truth of its own images.

On a procedural level, however, this unorthodox submission of affidavits remains significant, as it draws our attention to the relaxed rules of proof that governed the Tribunal's proceedings and permitted the prosecution to introduce the film as evidence. ${ }^{67}$ The standard of admissibility of filmic proof, at least in Anglo-American jurisprudence, centered on the doctrine of the authenticating witness. ${ }^{68}$ This doctrine, which continued to control in certain jurisdictions until well after Nuremberg, maintained that " $[t]$ he motion picture does not of itself prove an actual occurrence but the thing reproduced must be established by the testimony of witness." evidence" (evidence used to represent a state of affairs, as distinct from "real" evidence such as hair samples, etc. ${ }^{70}$ ), film was admissible "when it [was] shown that it [was] a correct likeness of the persons or objects which it purport[ed] to represent . . .."71 Not surprisingly, what constituted a "correct likeness" was a question that excited considerable judicial debate. ${ }^{72}$ Yet because film was conceptualized as dependent upon the corroboration of eyewitness testimony, ${ }^{73}$ it was often barred not because of its inaccuracy, but

67. The Nuremberg prosecution, of course, did not wholly eschew the use of eyewitnesses. As already noted, Jackson, in a notable struggle with other members of the prosecution, sought to restrict the use of eyewitnesses. The prosecution's heavy reliance upon affidavits and documentary evidence had, however, the consequence of quickly turning the spectacular proceeding into a terrifically tedious affair. For an evocation of this tedium, see, e.g., REBECCA WEST, A TRAIN OF POWDER 1-22 (1955). For a discussion of the prosecution's use of documentary evidence, see JOHN MENDELSOHN, TRIAL BY DOCUMENT: THE USE OF SEIZEd ReCORDS IN THE UNITEd STATES PROCEedingS AT NÜRNBERG 15-18, 95-109 (1988); John Mendelsohn, Trial by Document: The Problem of Due Process for War Criminals at Nuernberg, 7 Prologue 227, 227-34 (1975). Finally, Nazi Concentration Camps was not the only film screened at Nuremberg. The prosecution showed sections of films made by the Nazis themselves (including footage from Leni Riefenstahl's Triumph of the Will, see 3 IMT, supra note 2, at 400-02; TAYLOR, supra note 10, at 200), as well as films documenting atrocities in the east, see 7 IMT, supra note 2, at 601, and a pogrom in a Jewish ghetto, see $3 \mathrm{id}$. at 536 . These films, however, were not placed at the rhetorical center of the prosecution's case as was Nazi Concentration Camps.

68. See Paradis, supra note 12 , at 235-47.

69. Id. at 250 (citing UAW v. Russell, 88 So. 2d 175 (Ala. 1956), aff'd, 356 U.S. 634 (1958)); see also Beattie v. Traynor, 49 A.2d 200, 204 (Vt. 1946) ("A photograph ... is merely a witness' pictured expression of the data observed by him .... and its admission when properly verified, rests on the relevancy of the fact pictured.").

70. See Paradis, supra note 12 , at 250.

71. Id. at 237 (quoting Kortz v. Guardian Life Ins. Co. of America, 144 F.2d 676 (10th Cir. 1944)).

72. Although the Nuremberg prosecution conceptualized film as the ideal neutral and veracious witness, early courts evinced a wariness toward filmic testimony. See, e.g., Massachusetts Bonding v. Worthy, 9 S.W.2d 388, 393 (Tex. Civ. App. 1928) ("It is a matter of common knowledge that pictures showing a person in action may be made very deceptive .....").

73. "[T]he mere picture . . . cannot be received except as a non-verbal expression to the testimony of some witness competent to speak to the facts represented." 3 JOHN H. WIGMORE, WIGMORE ON EVIDENCE § 790, at 218-19 (James H. Chadbourn ed., rev. ed. 1970). 
because of its redundancy: It offered no more than a needless repetition of information already supplied by the superior eyewitness. ${ }^{74}$ Furthermore, the failure to support filmic evidence with eyewitness testimony was also fatal, as the film would then be barred as hearsay. Without in-court corroboration, such evidence would provide no more than a declaration of material fact made by an out-of-court witness unavailable for adversarial cross-examination-the very definition of hearsay. Finally, of importance to the Nuremberg Tribunal, certain American jurisdictions had barred photographic proof not because it was cumulative or hearsay, but because it was "gruesome": Graphic pictures of injuries had been declared inadmissible in certain suits because their relevance as evidence was outweighed by their potential for prejudicing a jury. ${ }^{75}$

The enabling charter of the Nuremberg Tribunal solved these evidentiary problems by the simplest means possible: It declared that the trial would "not be bound by technical rules of evidence." The Tribunal, the charter declared, "shall adopt and apply to the greatest possible extent expeditious and nontechnical procedure, and shall admit any evidence which it deems to have probative value."${ }^{.76}$ The application of these relaxed evidentiary conventions was tested early in the trial when the defense vigorously objected to the prosecution's use of sworn affidavits of persons who could have been called to testify in court (a practice which, as we shall see, played a significant role in the screening of Nazi Concentration Camps). In response to the defense's objection, Jackson argued: "This Tribunal sits under a Charter which recognized the impossibility of covering a decade of time, a continent of space, a million acts, by ordinary rules of proof, and at the same time finishing this case within the lives of living men." ${ }^{.77}$ Exigency alone, however, did not justify these relaxed conventions of proof. The absence of a jury, Jackson argued, supported the idea that the war crimes trial was "no occasion for applying jury rules"; ${ }^{78}$ judges, as distinct from lay persons, could weigh the relevance of hearsay testimony and would be less susceptible to being swayed by tendentious or prejudicial arguments. The very idea of convening a military tribunal "instead of an ordinary court of law," he argued, "was in order to avoid the precedent-creating effect of what is done here on our own law and the precedent control which would exist if this were an ordinary judicial body." for the articulation and defense of principles of international law, the

74. See Paradis, supra note 12 , at $257-60$.

75. See, e.g., United States v. 88 Cases, More or Less, Containing Bireley's Orange Beverage, 187 F.2d 967, 975 (3d Cir.), cert. denied, 342 U.S. 861 (1951) (holding that trial court erred in admitting into evidence pictures of guinea pigs dying in agony from Vitamin $\mathbf{C}$ deficiency after being put on diet of orange drink).

76. London Agreement, Aug. 8, 1945, sec. V, art. 19, reprinted in $1 \mathrm{IMT}$, supra note 2, at 15.

77. 3 IMT, supra note 2 , at 543 .

78. 3 id.

79. 3 id. 
procedures that governed the conduct of the trial were deemed to except themselves from ordinary rules of evidence. Remarkable in this argument is the implication that ordinary evidentiary conventions both slow a trial and render it a blunter instrument for securing historical truth. By permitting evidence such as that supplied by the documentary Nazi Concentration Camps, the Tribunal acted not only in the interest of efficiency, but also in the interest of securing the most reliable and complete representations of unspeakable atrocities.

This observation is reinforced by the film's interesting soundtrack. The stentorian voices that read aloud the two affidavits lead us to assume that we are hearing George Stevens and E.R. Kellog in person, until the documentary's narration begins, speaking in the same professional voice we took to be Kellog's. It is only then that we realize that the transcript is wrong in reporting that "the voices of the respective affiants were reproduced reading them." In fact, we are listening to an unnamed narrator, who, by standing in for Stevens and Kellog, claims a central omniscience as the speaker of what the camera sees. The narrator thus supplies the voice not of a military historian or soldier witnessing the liberation of the camps, but of the camera itself. As such, it seems to speak with the same objectivity that the images claim for themselves.

The film fades to a map of Europe, marked by its prewar borders, upon which appear, in rapid proliferation, the names not of nations and capitals, but of obscure locales, until the center of the continent is crowded with the names of the Lagers (concentration camps). During the course of its presentation, the documentary visits a dozen of these camps, each of which is treated discretely and introduced with a graphic of a chipped brick wall upon which is superimposed, in block letters, PENIG (sic) CONCENTRATION CAMP, OHRDRUF CONCENTRATION CAMP, NORDHAUSEN CONCENTRATION CAMP, BUCHENWALD CONCENTRATION CAMP, DACHAU CONCENTRATION CAMP. Upon this brick wall appears what looks like a splattering of blood, though it is difficult to say, as the film is shot entirely in that finely shaded black and white that has powerfully overdetermined our images of the period. Nazi Concentration Camps, however, could have been a color film. Technicolor, though an expensive process, was available at the time of the liberation of the camps; and Stevens filmed much of the footage from Dachau with the same hand-held color camera with which he had kept a personal filmic diary of the making of his popular Gunga Din. ${ }^{81}$ The Army, however, fearing that the three-track projectors necessary for showing Technicolor films would be unavailable in courtrooms and movie

80. 2 id. at 433 .

81. See George Stevens: A FilmMakeR's JouRney (Castle Hill Productions 1984). Stevens's color footage can be seen at the U.S. Holocaust Memorial Museum. 
houses, decided to rely exclusively on monochrome for its documentaries, a decision that was instrumental in shaping persistent cultural images of the Holocaust as an event that unfolded in black and white. ${ }^{82}$

The film begins with the camp in Leipzig, where shortly before the liberation hundreds of prisoners were locked in a barrack and torched alive by the retreating Nazis. The camera shows the scar of the building upon the blackened earth surrounded by dirty snow, and then draws close, examining the brittle remains of burnt corpses. It is an image that defines the visual legend of the film, which does not capture the active commission of atrocities, but focuses instead on the wounds they leave behind-upon the earth, the dead, and the survivors. Such images powerfully suggest belatedness: The liberators have arrived, but they have come too late. No specific regimen of punishments could have reduced the victims to this horrific state, the film seems to say. Only a vast and systematic pattern of perverse cruelty could account for the magnitude of the wounds seen by the camera.

At times the camera rebels against its own belatedness, as when it relies upon reenactments to make vivid the horror. Yet these moments are the film's least effective: Russian POWs, recreating how they would scavenge for food in camp garbage, turn what was a cruel competition for survival into a comradely jostling for the camera, their faces creased with smiles. Equally awkward are those moments when the camera overly aestheticizes its subject. The film offers a close-up through the camp's fence of a bearded camp survivor, his head framed by a rectangle of barbed wire. The frame within the frame, a perfectly adequate and appropriate technique for a Hollywood shot, seems in this context mannered and indecent. ${ }^{83}$ Indeed, the man's grim vanquished stare haunts not simply because it abandons any pretense of posturing for the camera, but because it suggests contempt toward this selfconscious effort to aestheticize his experience. The image succeeds despite itself, for it draws attention to the horror of the survivor through the plight of the camera.

The camera struggles to find the proper perspective, the appropriate angle from which the camps should be seen. While it is commonplace today to speak of the camera's exclusions and aggressions, ${ }^{84}$ in Nazi Concentration Camps we catch glimpses of a more unusual phenomenon: the camera's confusion and

82. Steven Spielberg, for example, describing his choice to film Schindler's List in black and white, stated, "I knew Schindler's List had to be black and white, the moment I decided to make the movie." Zoë Heller, The Real Thing, THE INDEPENDENT (London), May 23, 1993, at 24. By contrast, Alain Resnais relied upon the juxtaposition between documentary footage in black and white and contemporary footage in color for much of the unsettling force of his $1955 \mathrm{film}$, Night and Fog.

83. For an instructive discussion of the difficulty and indecency of aestheticizing horror in photographs, see JANET MALCOLM, The View from Plato's Cave, reprinted in DIANA AND NIKON: EsSAYS ON THE AESTHETIC OF PHOTOGRAPHY 75 (1980).

84. See, e.g., BILL NICHOLS, REPRESENTING REALITY: IssuES AND CONCEPTS IN DOCUMENTARY 7 (1991); see also SONTAG, supra note 66, at 7 ("There is an aggression implicit in every use of the camera."). 
embarrassment. Its efforts to occupy a position of detached neutral observation-the putatively privileged position of the realist documentary ${ }^{85}$-merely call attention to a central confusion that leaves its traces throughout the film. Even those moments when the survivors treat the camera as invisible are unnerving, as we are so accustomed to posing for a photograph that the subjects' capacity to stare past the camera's gaze becomes revealing. Close-ups of former inmates show the twisted facial geometries and afflicted eyes of the demented. Their very obliviousness to the filming eye, the absence of any defense against the camera's intrusions, makes their isolation and despair manifest. The camera functions, then, less as the invisible witness imagined by theorists of realist documentary and members of the Nuremberg prosecution. Instead, it serves to provoke-we learn of the survivors' world through their reaction (or lack of one) to the lens's awkward probings.

At other times, it is the survivors' awareness of the camera that provides moments of inadvertent revelation. In a peculiar shot, three former inmates are caught posing not for the filmmaker, but for a still photographer also captured within the documentary's frame. In the shot within the shot, we see the three survivors-two emaciated men, stripped to their waists, seated on either side of a third, standing, clothed in layers of rags-directing gaunt and macabre smiles toward the photographer, like three members of a grotesque reunion. Here, however, it is the absurdity of their efforts to satisfy the roseate expectations of the camera that creates a haunting image.

In another shot, an attractive woman lifts her skirt to reveal puncture wounds upon her buttocks inflicted by Nazi torturers. She is filmed, for unknown reasons, standing on the rooftop of an apartment building, and as she stares over her shoulder back at the camera, her skirt gathered at her waist, we can see, stretching behind her, the ruins of a bombed and ravaged township. The film thus connects the woman's body to the townscape: All forms of property have been violated by the Nazis. Yet the very effort to document the Nazis' sexual cruelty inadvertently creates a pornographic moment, as the film offers her body as an object to be voyeuristically surveyed. ${ }^{86}$

But the most remarkable, if not grotesque, instance of filmic posturing occurs in a sequence in which the camera interrogates a former American POW at the Mauthausen camp. Up until this point, the film has been guided exclusively by the voiceover of the invisible narrator. Now, as the camera focuses upon this handsome young American who towers above the other liberated POWs crowding about him, we hear, for the first time, the voice of a person in the film. Compared to the walking corpses and bedridden patients that largely people the film, the American soldier makes a healthy, even robust

85. See William GuYN, A Cinema of Nonfiction (1990).

86. For an examination of how efforts to critique the pornographic recapitulate its representational logic, see SusAn StEWART, CRIMES OF WRITING: PROBLEMS IN THE CONTAINMENT OF REPRESENTATION 235-72 (1991). 
impression. As he stands before the camera, he begins his grim narrative with a rather buoyant introduction - "I am Lt. (senior grade) Jack H. Taylor, U.S. Navy, from Hollywood, California"'-and then adds, "'Believe it or not, this is the first time I have ever been in the movies." "\$87 The burden of credibility falls, then, not upon his enumeration of the various forms of execution used at the Mauthausen camp- -"by gas, by shooting, by beating, that is beating with clubs, by exposure, that is standing out in the snow naked for 48 hours and having cold water thrown on them in the middle of winter-starvation-dogs-and pushing over a hundred-foot cliff" ${ }^{88}$ - but rather upon the fortuity of his appearance on the big screen. And as the camera moves from his healthy complexion to mass graves, we glimpse the perverse logic behind his ironic celebration of his filmic debut.

The horrors mount and intensify as the film journeys to the camps at Buchenwald, Dachau, and Bergen-Belsen. The camera lingers upon naked, emaciated bodies strewn upon a barrack floor. Suddenly, one twitches and we realize that unlike the other mounds of corpses, these people are, in fact, alive. It is a jarring moment, as what appears a "still" turns into a moving image. "These are the survivors," documentary concludes with the now-famous footage of British bulldozers pushing a veritable mountain of bodies into a mass grave. As the dead and dirt cascade down the deep pit, the narrator ends with the flat declaration, "This was Bergen-Belsen." ${ }^{90}$ The horrific images render any additional verbal summary or commentary superfluous.

Yet just as the documentary calls attention, however inadvertently, to the camera's intrusions, it relies upon a final, notable rhetorical technique to authenticate what it has seen: Lest anyone doubt the veracity of its images, the documentary provides shot after shot of eyewitnesses viewing the very legacy of atrocities that the film records. We watch Generals Eisenhower, Bradley, and Patton examine, ashen-faced, the camps; we track the journey of a delegation of congressmen; we follow the footsteps of GIs filing past rows of bodies. The technique harks back to the affidavits that swear to the film's authenticity. Again, the documentary supplies within its own frame witnesses to corroborate the truth of its representations.

The spectacle of witnessing the act of witnessing serves a further end distinct from evidentiary interests. Many of the film's most powerful images are shots of Germans forced to bear witness to Nazi barbarity. From a field of rotting exhumed corpses, the film cuts suddenly to a promenade of smiling Weimar women, dressed in their Sunday best, strolling along a tree-lined road, on their way to view the camps by "invitation" of the Americans. Compelled

87. 30 IMT, supra note 2 , at 462,467 .

88. $30 \mathrm{id}$. at 468 .

89. $30 \mathrm{id}$ at 470 .

90. 30 id. at 472 . 
to witness the legacy of Nazi atrocities, the "good" German citizens are later captured in various attitudes of disgust and distress, stifling sobs or nausea by burying their faces in handkerchiefs. ${ }^{91}$ These scenes reappear throughout the film. The memoirists' device of depicting the screening of the film at the trial through a description of the reaction of the defendants ${ }^{92}$ thus powerfully echoes the visual structure of the film itself. And if the scenes of Germans pressing tightly balled kerchiefs to their faces anticipate the memoirists' portraits of the defendants, they also present the same problems implicitly raised by the works of Gilbert, Neaves, and Taylor. For the trial eschewed precisely the argument to which the film and the memoirists seem committed: that the German people shared in the deeper culpability for the atrocities perpetrated by their leaders and state. In his opening statement, Jackson specifically declared that the prosecution did not seek to condemn a nation in its entirety: "[W]e have no purpose to incriminate the whole German people." ${ }^{93}$ The film, by contrast, offers no such guarantees, as it disperses responsibility for what happened to those who became complicitous in crimes through the tacit and cowardly tolerance of places they chose to know nothing about. ${ }^{94}$

Yet the sanction imposed upon the citizens living in the environs of Dachau and Buchenwald ultimately is no more than the punishment of witnessing. It is, in certain respects, an odd punishment, for although we might take grim satisfaction in watching the Germans forced to confront the legacy of their shame and quiescence, the film places the "innocent" viewer in much the same position as the German civilians. While there is presumably a significant difference between being forced to witness such horrors first-hand and viewing them through the camera's mediation, we have also noted that the prosecution's very reliance upon film was meant to belie this distinction. If we think of the act of viewing as a sanction, then the film seems to impose virtually the same punishment upon us.

The act of coerced witnessing suggests itself as an appropriate response to the civilians' quiescence, less because the punishment fits the crime than because it violently abrogates it. Whatever evasions and duplicities permitted a person to sweep the camps from his or her frame of vision during the war

91. The documentary erroneously attributes this footage, which includes shots of Germans filing past a table displaying flayed human skin and shrunken heads prepared by the Nazis, to the liberation of Arnstadt Concentration Camp. In fact, the footage is from Buchenwald, a fact corrected in the published transcript of the documentary. See 30 id. at 469.

92. See supra notes $32-37$ and accompanying text.

93. 2 IMT, supra note 2 , at 102.

94. In a remarkable column in The Nation, James Agee condemned the showing of clips of atrocity films in the United States precisely because such films "pin the guilt for these atrocities on the whole German people." James Agee, Films, THE NATION, May 19, 1945, at 579. Dismissing the films as mere "propaganda," Agee pointed out "I have not felt it necessary to see the films themselves." Id. He further claimed that the showing of such pictures makes Americans worse "in some respects, than the Nazis," for such screenings have the effect of spreading blame over the entire German citizenry. Id. 
cannot survive contact with the world captured on film. The film does not simply instruct or produce visual knowledge of atrocity; rather, it overwhelms one's senses, creating an irrefutable imprint upon the mind, a trauma of sight. The ultimate coercion issues not from the conquering army that commands the act of witnessing, but from the tangible evidence of atrocity itself. The corpses force their memory upon the coward's mind.

The film, however, provides few clues as to who is responsible for the atrocities in a more tangible, i.e., juridical, sense. The camera focuses briefly on the face of Josef Kramer, the former commandant of Belsen, whose unusually brutal appearance-small eyes cast to the side; thick neck; beefy cheeks ribboned with Schmiesse, the dueling scars that were points of pride for members of the fraternal Burschenschaften-makes him a helpful exemplar of the kind of person responsible for such crimes. But besides its brief focus upon this specimen of evil, the film fails to clarify more specific questions of legal responsibility. Indeed, the camera's struggles to find an adequate visual idiom suggest the difficulties of enlisting the evidence of such atrocities to support a criminal case organized around the charge of aggressive militarism. These difficulties are only underscored by the circumstances of the film's awkward insertion at the trial, bearing no ostensible connection to the testimony about either the Austrian Anschluss that preceded it, or the seizure of the Sudetenland that followed it. But if the film unsettles both the very conventions of documentary representation through which its images are discomfittingly framed, and the legal argument it was meant to support, how was Jackson able to see his way to enlisting this evidence into his legal case?

\section{HARMONZZING THE EVIDENCE WITH THE ARGUMENT}

An answer can be hazarded by considering more closely the relationship between the film's principal constitutive elements-its images and narration. Commenting on the role that captions play in news photography, the French director Jean Luc Godard once observed, "This photograph, like any photograph, ... is physically mute. It talks through the mouth of the text written beneath it." "95 By contrast, in the theory of documentary realism, sound is meant to be "'merely a supplementary support of representation; it must integrate itself docilely with the mimed object." ${ }^{\prime 96}$ Yet the closer we study Nazi Concentration Camps, the more it becomes clear that the narration does not simply strengthen the verisimilitude of the image, ${ }^{97}$ on the contrary, the voice of the commentary comes ultimately to assert control over the film's

95. SONTAG, supra note 66, at 108 (quoting film A LETTER TO JANE (1972)).

96. GUYNN, supra note 85, at 155 (quoting Roland Barthes, Upon Leaving the Movie Theater, in ApPaRATUS: CINEMATOGRAPHIC APPARATUS: Selected Writings 2 (Theresa Hak Kyung Cha ed., Bertrand Augst \& Susan White trans., 1981).

97. Id. 
images. While the pictures captured by the camera's eye produce a "'visual impact ... such as will nullify explanation, ${ }^{\prime \prime 98}$ the narration attempts to restrict and secure the meaning of the evidence that has been presented to our eyes.

In Nazi Concentration Camps, the narrator, as we have observed, remains nameless, and often seems to do no more than clarify what the camera sees: "Some have gangrenous wounds."" "They see the woodshed where limecovered bodies are stacked...." "Victims bear the marks of violent deaths." "There are two heads which have been shrunk to one-fifth their normal size." "La2 "Large pieces of skin have been used for painting pictures, many of an obscene nature." ${ }^{103}$ At other times, however, the narrator's omniscience is clearly greater than the film's, as he is able to provide information unavailable to the camera: "The victims are mainly Poles and Russians with considerable numbers of French and other nationalities also included in the camp roster."104 "The Nazis maintained a building at the camp for medical experiments and vivisections with prisoners as guinea pigs." 105 The narration is relatively flat and laconic, free of the histrionics and rhetorical flourishes one often finds in wartime documentaries made for weekly newsreels. In fact, the entire text of the seventy-minute film takes up no more than eleven pages of the Tribunal's massive published catalogue of "Documents and Other Material in Evidence."106 Indeed, it is the very flatness and terseness of the commentary that most powerfully creates the impression that it is the images, and not the words, that are speaking.

Yet this terseness, upon closer inspection, calls attention to certain interesting omissions. The word "Jew," for example, is mentioned only once in the entire film, and in such a manner as to obscure any suggestion that Nazi terror was directed against Jews as a group: "The 4,000 Ohrdruf victims are said to include Poles, Czechs, Russians, Belgians, Frenchmen, German Jews and German political prisoners." 107 Any further mention of terror directed specifically against Jews is suggested in a highly elliptical manner: "Under the guise of an insane asylum this had been the headquarters for the systematic murder of 35,000 Poles, Russians, and Germans sent here mainly for political and religious considerations." ${ }^{108}$ This is not to suggest that the film deliberately failed to specify the special atrocities reserved for Jews; the camps

\footnotetext{
98. SONTAG, supra note 66, at 111 (quoting Robert Frank).

99. $30 \mathrm{MMT}$, supra note 2 , at 462 .

100. $30 \mathrm{id}$ at 463 .

101. $30 \mathrm{id}$ at 466 .

102. 30 id. at 469 .

103. $30 \mathrm{id}$.

104. 30 id. at 467 .

105. 30 id. at 469 .

106. 30 id. at 462-72.

107. $30 \mathrm{id}$. at 464 .

108. $30 \mathrm{id}$.
} 
liberated by the British and Americans were not, technically speaking, centers of extermination. Nor, however, were the liberators lacking evidence of the Nazis' vast genocidal project directed against European Jewry. The Germans' retreat before Soviet advances had led to the liquidation of the death camps in the East, and by the time the Allies reached Bergen-Belsen, for example, the camp was already hideously overcrowded with Jews forcibly marched westwards. ${ }^{109}$ If we now know that Lagers such as Bergen-Belsen and Dachau were not death camps per se (Belsen ironically was a "model" camp until late 1944, when it began receiving internees from the East ${ }^{110}$ ), the photos and film of the liberation of these camps "more than any other aspect of the Holocaust imprinted on the Western consciousness the images which have come to characterize the Final Solution."111 Indeed, as Neal Ascherson has observed, " $\Pi \mathrm{I}$ t was to be many years before the word 'Auschwitz' (implying the gassing of millions), replaced 'Belsen' ... as the ultimate metaphor of evil."112

The film's understanding of its own images is revealed, then, in a small but telling description. As the camera moves across the corpses littered about Buchenwald, the narrator declares, "Pictorial evidence of the almost unprecedented crimes perpetrated by the Nazis at Buchenwald Concentration Camp." ${ }^{.13}$ Noteworthy in this characterization is the insertion of the word "almost." Whether the Nazis" genocidal campaign was "unique" or "unprecedented," has, of course, emerged as one of the most contentious issues in Holocaust studies. While some scholars continue to emphasize the monstrous singularity of the Nazi genocide and question the motives of those who would challenge such an understanding, ${ }^{114}$ others have attempted to assimilate the extermination of the Jews into a more "conventional" history of atrocity, one that finds ample precedents in Stalin's gulags and echoes in Pol Pot's killing fields. ${ }^{115}$ Yet regardless of one's position in this debate, it

109. At the time of its liberation, roughly 40,000 Jews were interned at Belsen-roughly two-thirds of its final population. See JON BRIDGMAN, THE END OF THE HOLOCAUST: THE LIBERATION OF THE CAMPS 34 (1990); see also MARTIN GILBERT, ATLAS OF THE HOLOCAUST 206-26 (1993) (documenting death marches towards end of war leading up to Allied liberation of Belsen and other camps).

110. See BRIDGMAN, supra note 109.

111. Id. at 14.

112. Neal Ascherson, The Film Britain Hid from Germany, THE OBSERvor (London), Sept. 8, 1985, at 7. Recent publications commemorating the fiftieth anniversary of the end of the war continue to associate Buchenwald and Belsen with centers of genocide. See, e.g., Tom Infield, Witness, PHILA. INQuIRER MAG., Apr. 9, 1995, at 12, 15 ("This is how America learned of the Holocaust. It was only when U.S. troops began stumbling onto concentration camps as they overran the heart of Germany in April 1945 that America came to realize the absolute evil of the Nazi regime.").

113. $30 \mathrm{IMT}$, supra note 2, at 468 (emphasis added).

114. See, e.g., DAVIDOWICZ, supra note 21, at 15-19; STEVEN T. KATZ, The "Unique" Intentionality of the Holocaust, in POST Holocaust Dialogues 287, 290, 310 (1983).

115. For a revisionist account of the Holocaust arguing against the thesis of uniqueness, see ERNST NOLTE, DER EUROPÄISCHE BÜRGERKRIEG, 1917-1945, at 503 (1987) (noting parallels between German National Socialism and Russian Communism, especially with regard to deportation of ethnic minorities). For a discussion of the controversy within German academic circles about the causes and nature of the Holocaust (the so-called Historikersstreit), see CHARLES S. MAIER, THE UNMASTERABLE PAST: HISTORY, 
should be clear that the narration's use of "almost" to modify "unprecedented" does not indicate a historically nuanced acknowledgment of other instances of extreme organized cruelty.

The crimes perpetrated by the Nazis at Buchenwald are "almost" unprecedented not because genocide has its historical antecedents, but because the film does not understand itself to be a document about genocide. The insertion of "almost" serves purposes that are at once strategic-the modest qualification appeals to the naturally incredulous mind that associates the rhetoric of the "unprecedented" with the ends of propaganda-and revelatory. It reveals that the film does not perceive its images as bearing witness to the astonishing crimes perpetrated against Europe's Jewish population. ${ }^{116}$ The visual organization of the film insists on the veracity of its images, yet the narration suggests that the film itself remains deeply confused by what it has seen.

But if Nazi Concentration Camps is not about genocide, then what is it about? The narration offers no unequivocal answers or rigid explanatory framework to make intelligible its accompanying images. Yet in the terse words that narrate the camera's entry into each camp, a larger understanding begins to emerge:

More than 200 political prisoners were burned to death in this concentration camp near Leipsig [sic].

...

At this concentration camp in the Gotha area, the Germans starved, clubbed and burned to death more than 4,000 political prisoners over a period of 8 months. ...

This is Breendonck prison in Belgium. It offers evidence of Nazi brutality imposed on Belgian patriots during the period of German occupation.

The slave labor camp at Nordhausen liberated by the 3rd Armored Division, 1st Army.

At least 3,000 political prisoners died here at the brutal hands of SS troops....

The report lists the surviving inmates [of Buchenwald] as representing every European nationality. ...

…

In the official report, the Buchenwald camp is termed an "extermination factory." ... By these means, the report continues, 
many tens of thousands of the best leadership personnel of Europe have been exterminated. ${ }^{117}$

By its own terms, then, Nazi Concentration Camps is a film about political terror and the excesses of war. It documents a barbaric campaign to exterminate political enemies of a brutal regime. It exposes the horrific mistreatment of prisoners of war, and the enslavement of civilians to service a ruthless war machine. It bears witness to spectacular excesses of cruelty and reveals the administrative and technological apparatus that made possible campaigns of mass murder. It does so, however, in a manner that understands extermination in terms of the perverted logic of political control and military conquest. The film understands the crimes to be the consequence of aggressive militarism rather than genocide. Yet the question remains: Did the film misinterpret its own images?

The question raises interesting issues about the meaning of documentary evidence. Writing about a British film team's documentary covering the liberation of the camps, Neal Ascherson has observed, "The filmmakers had not, in fact, had time to grasp the horror within the horror. The scale of the 'Final Solution of the Jewish Problem' had scarcely dawned on them ...."118 Whether this also explains the narrative posture of Nazi Concentration Camps ultimately, however, is of marginal concern. More interesting remains the fact that some fifteen years after its screening at Nuremberg, Nazi Concentration Camps was shown at the Eichmann trial as evidence of the Nazis' campaign of extermination directed specifically against the Jews. ${ }^{119}$ At roughly the same time, Nazi Concentration Camps made its own Hollywood debut, appearing as the film within the film of Stanley Kramer's Judgment at Nuremberg. ${ }^{120}$ Starring Spencer Tracy and Burt Lancaster, Judgment at Nuremberg offered a dramatization of the trial not of the major war criminals before the International Military Tribunal, but of a follow-up trial involving defendants in the Reich Ministry of Justice and other legal functionaries. ${ }^{121}$ Devoted to examining how members of a legal apparatus, in particular judges, could pervert institutions of justice, Judgment at Nuremberg reaches its dramatic peak when the prosecution screens documentary footage of the liberation of the concentration camps. The film within the film is, of course, none other than Nazi Concentration Camps, and director Stanley Kramer drives home its power by using precisely the

117. $30 \mathrm{IMT}$, supra note 2 , at $462-68$.

118. Ascherson, supra note 112 , at 7.

119. See 3 THE TRIAL OF ADOLF EICHMANN: RECORD OF PROCEEDINGS IN THE DISTRICT COURT OF JERUSALEM 1283-85 (1993).

120. JudGMENT AT NUREMBERG (Metro-Goldwyn-Mayer 1961).

121. United States v. Josef Altstoetter et al. (also known as the Justice case), in 3 TrIALS of WAR Criminals Before the Nuernberg Miltary Tribunals Under Control Council LaW No. 10 (1949-53). 
techniques used by the memoirists: He cuts from the film within the film back to the Hollywood drama, as we now see shock and revulsion etched on the faces of Richard Widmark and Burt Lancaster. In Judgment at Nuremberg, however, Nazi Concentration Camps is again comprehended as it was at the Eichmann trial一as irrefutable evidence of the Holocaust.

We find this understanding of Nazi Concentration Camps also at work in the film's most recent use in a trial setting. In 1985, some forty years after the film's Nuremberg "premiere," a Canadian prosecutor again called $\mathrm{Nazi}$ Concentration Camps to the stand-this time in the criminal trial of Ernst Zundel, a notorious Holocaust denier. ${ }^{122}$ Zundel, who had arranged for the publication of Did Six Million Really Die?, a tract that claimed the Holocaust was a Zionist swindle, was charged with violating a little-used portion of the Canadian criminal code prohibiting the publication of false statements "likely to cause injury or mischief to a public interest."123 Because the indictment charged Zundel with knowingly publishing false statements, the court reasoned that it was incumbent upon the prosecution to prove the falsity of Zundel's Holocaust denials. Toward this end, Nazi Concentration Camps was shown to the jury, now as evidence of precisely those crimes against the Jews that the film fails to mention. Indeed, at the film's conclusion, the prosecutor announced to the court, "'That is the case for the Crown, Your Honour." 124

Ironically, then, Nazi Concentration Camps has been used as irrefutable proof of an event the film did not originally see itself as documenting. ${ }^{125}$ Though ironic, this is not entirely surprising, as we are reminded of the plasticity of visual evidence, the way identical images can sponsor multiple interpretations and support different legal arguments. Yet regardless of how Nazi Concentration Camps has been comprehended in other contexts, of interest for our purposes is how the documentary's narration-the understanding that it supplies of its own images-made the film available for juridical use at Nuremberg. By framing its horrific scenes in a narrative about perverted militarism and war's excess, the film harmonized its imagery with Jackson's legal argument.

122. Regina v. Zundel, 58 O.R.2d 129 (Ont. Ct. App. 1987).

123. R.S.C., ch. C-34 $\$ 177$ (Supp. 1970) (Can.).

124. Leonidas E. Hill, The Trial of Ernst Zundel: Revisionism and the Law in Canada, 6 SiMON WIESENTHAL CENTER ANN. 165, 184 (1989). Zundel was convicted and sentenced to two years in prison. On appeal, however, the conviction was overturned. The appellate court reasoned, inter alia, that Nazi Concentration Camps had been improperly shown to the jury at trial. Because the nameless screenplay writer and narrator were unavailable for cross-examination, the documentary failed under the rules of hearsay. See Regina v. Zundel, 58 O.R.2d 129, 195-200 (Ont. Ct. App. 1987). For additional discussion of the Zundel case, see Lawrence Douglas, Wartime Lies: Securing the Holocaust in Law and Literature, 7 YALE J.L. \& HUMAN. 367, 387-89 (1995). As noted above, the relaxed rules of evidence that controlled the Nuremberg trial permitted the film's showing.

125. As a related matter, it seems ironical that Eisenhower's famous words should be inscribed upon the entrance to the U.S. Holocaust Memorial Museum, as it is far from clear that by speaking of things that "beggar description" Eisenhower meant the mass extermination of Europe's Jews. 
Jackson, as we have seen, understood the Nazis' central crime as the waging of aggressive war. This offense, though supported by an unsteady scaffolding of positive and customary law, nevertheless left intact deeper concepts of ordered legality and provided, so the prosecution argued, the proximate cause for other Nazi crimes. Granted, the Nuremberg prosecution extensively detailed the Nazis' savagery toward the Jews in later stages of the trial, ${ }^{126}$ and Jackson, to his credit, devoted a lengthy section of his opening statement to detailing "Crimes against the Jews,"127 during which he powerfully declared, "It is my purpose to show a plan and design, to which all Nazis were fanatically committed, to annihilate all Jewish people."128 Yet his understanding of this design of annihilation is noteworthy:

Nor was [the policy of starvation and extermination] directed against individual Jews for personal bad citizenship or unpopularity. The avowed purpose was the destruction of the Jewish people as a whole, as an end in itself, as a measure of preparation for war, and as a discipline of conquered peoples. ${ }^{129}$

At this critical moment, Jackson invoked, if not the term, then the logic of genocide-the extermination of an entire people as an end in itself. He was close at this point to following the lead of the indictment, which specifically used the word "genocide" to describe the Nazis' annihilation of European Jewry. ${ }^{130}$ But the neologism, first coined by Raphael Lemkin in 1944 to describe the extermination of the Jews, ${ }^{131}$ was never again used at Nuremberg. Indeed, Jackson himself listed "the destruction of the Jewish people" not simply as an end unto itself, but also as a means. The Jews, he argued, were used as exemplars of Nazi discipline to other citizenries under Nazi subjugation, ${ }^{132}$ and their persecution eliminated an obstacle to aggressive war. ${ }^{133}$ His reasoning, of course, is question-begging-how can such annihilation be understood as a "measure of preparation for war"?-_and historically suspect. Scholars of the Holocaust, for example, have amply demonstrated how the Final Solution not only did not serve any military end,

126. The prosecution's presentation, however, suffered from remarkable omissions: The French prosecution, responsible for presenting evidence under the fourth count of the indictment ("Crimes Against Humanity"), mentioned the Jews as a target of Nazi violence on but one occasion. See TAYLOR, supra note 10 , at 296.

127. 2 IMT, supra note 2 , at 118-27.

128. $2 \mathrm{id}$. at 118 .

129. 2 id. at 119.

130. The indictment's description of genocide includes the extermination of "Jews, Poles, and Gypsies and others." $1 \mathrm{id}$. at 44. Yet consistent with Jackson's approach, the crime of genocide is named under the third count, "War Crimes," and not under the fourth count, "Crimes Against Humanity." 1 id. at 43-44.

131. See Robinson, supra note 116, at 6 (citing RAPHAEL LEMKIN, AXIS RULE IN OCCUPIED EUROPE 79-95 (1944)).

132. 2 IMT, supra note 2, at 118 ("The ghetto was the laboratory for testing repressive measures.").

133. 2 id. at 127 ("The purpose ... of getting rid of the influence of free labor, the churches, and the Jews was to clear their obstruction to the precipitation of aggressive war."). 
but channeled away critical resources from the war effort. ${ }^{134}$ Yet the very vulnerabilities of Jackson's argument highlight his attempt to translate shocking images of genocide into an idiom consonant with, and supportive of, the prosecution of functionaries responsible for a campaign of renegade militarism.

\section{CONCLUSION}

In The Reawakening, Primo Levi describes his first encounter after his liberation from Auschwitz with a man from "the civilized world." Standing before a well-dressed lawyer - an "extremely courteous and benevolent" person-Levi recalls feeling a powerful need to unburden himself of all that he had witnessed:

I had a torrent of urgent things to tell the civilized world: . . things which (it seemed to me) ought to shake every conscience to its very foundations. . . . I spoke at dizzy speed of those so recent experiences of mine, of Auschwitz nearby, yet, it seemed, unknown to all, of the hecatomb from which I alone had escaped, of everything. The lawyer translated into Polish for the public. Now I do not know Polish, but I know how one says 'Jew' and how one says 'political'; and I soon realized that the translation of my account, although sympathetic, was not faithful to it. The lawyer described me to the public not as an Italian Jew, but as an Italian political prisoner. ${ }^{135}$

Astonishing in its own detail, Levi's story brilliantly captures the small strategic distortions that both made possible, and resulted from, the effort of the Nuremberg prosecution to comprehend the extermination of European Jewry. In translating schemes of annihilation into excesses of war, Jackson and the narration of Nazi Concentration Camps protected not only the jurisdictional reach of the Tribunal, but also preserved the underlying jurisprudential vision that sought to extend international law into the conflicts between nations but not into the darkest bowels of a reprobate sovereign. By treating genocide as ancillary to the crime of militarism, Jackson and the documentary's narration supplied the formal links between the legal case and the visual evidence enlisted to support it. Like the actions of the lawyer whom Levi encounters, Jackson's efforts remained sympathetic, though less than faithful, to the history his arguments had to defend.

One can, of course, claim it is unfair to condemn prosecutorial teams, burdened with shaping a vast amount of evidence into a complex legal case in a short period of time, for failing to be fully attentive to the crimes against Europe's Jews. Yet the failure to address Nazi genocide adequately was not

134. See RAUl Hilberg, THE Destruction of THE EuROPEAN JeWs 644-46 (Harper Colophon 1978) (1961).

135. Primo Levi, The Reawakening 54 (Stuart Woolf trans., Little, Brown \& Co. 1965) (1963). 
simply an example of overtaxed prosecutors revealing the same indifference to the fate of the Jews that the Allies had shown during the war. Indeed, on a juridical level, the prosecution's efforts can be seen as a success. By "reading" Nazi Concentration Camps in a manner that recuperates the power of law to assimilate the atrocities on film into a novel, though comprehensible, idiom of criminal transgression, Jackson performed something of a legal tourde-force. Just as the narration of Nazi Concentration Camps comes to exercise control over the images it is meant simply to clarify, so the voice of the law, as uttered by Jackson, came to exercise authority over evidence that threatened to expose the law's limits. If this success came at the cost of misreading the film's images, this merely underscores the extraordinary difficulty of accommodating a crime that "lies outside speech and . . outside reason"136 to available conceptions of justice and legality. And it reveals that in a trial, even evidence that claims to speak for itself of atrocity ultimately must be spoken for. The legal meaning of such evidence must be secured even as what it shows cannot be denied.

136. STEINER, supra note 16 , at 123. 
